\title{
Hanford Immobilized Low-Activity Waste Product Acceptance
} Test Plan

by

D. Peeler

Westinghouse Savannah River Company

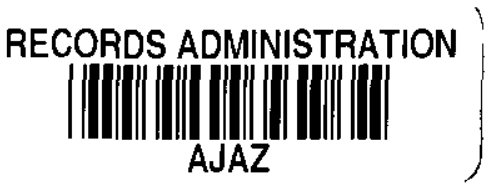

Savannah River Site

Aiken, South Carolina 29808

J. D. Vlenna

B. P. McGrail

This paper was prepared in connection with work done under the above contract number with the U. S. Department of Energy. By acceptance of this paper, the publisher and/or recipient acknowledges the U. S. Government's right to retain a nonexclusive, royalty-free license in and to any copyright covering this paper, along with the right to reproduce and to authorize others to reproduce all or part of the copyrighted paper. 


\section{DISCLAIMER}

This report was prepared as an account of work sponsored by an agency of the United States Government. Neither the United States Government nor any agency thereof, nor any of their employees, makes any warranty, express or implied, or assumes any legal liability or responsibility for the accuracy, completeness, or usefulness of any information, apparatus, product, or process disclosed, or represents that its use would not infringe privately owned rights. Reference herein to any specific commercial product, process, or service by trade name, trademark, manufacturer, or otherwise does not necessarily constitute or imply its endorsement, recommendation, or favoring by the United States Government or any agency thereof. The views and opinions of authors expressed herein do not necessarily state or reflect those of the United States Government or any agency thereof.

This report has been reproduced directly from the best available copy.

Available to DOE and DOE contractors from the Office of Scientific and Technical Information, P.O. Box 62, Oak Ridge, TN 37831; prices available from (615) 576-8401.

Available to the public from the National Technical Information Service, U.S. Department of Commerce, 5285 Port Royal Road, Springfield, VA 22161. 


\title{
HANFORD IMMOBILIZED LOW-ACTIVITY WASTE PRODUCT ACCEPATNCE TEST PLAN (U)
}

\author{
J.D. Vienna, D.K. Peeler, and B.P. McGrail
}

Westinghouse Savannah River Company, Aiken, SC Pacific Northwest National Laboratory, Richland, WA

Westinghouse Savannah River Company

Savannah River Site

Aiken, SC 29808 


\title{
Hanford Immobilized Low-Activity Waste Product Acceptance Test Plan
} Tanks Focus Area Technical Task Plans RL3-7-WT-31 and SR1-6-WT-31

\author{
John D. Vienna, David K. Peeler ${ }^{\ddagger}$, and B. Peter McGrail
}

Pacific Northwest National Laboratory, Richland, WA 99352

${ }^{\ddagger}$ Westinghouse Savannah River Company, Aiken, SC 29808

March 1999

\section{Introduction}

The Hanford Site has been used to produce nuclear materials for the U.S. Department of Energy (DOE) and its predecessors. A large inventory of radioactive and mixed waste, largely generated during Pu production, exists in 177 underground single- and double-shell tanks. These wastes are to be retrieved and separated into low-activity waste (LAW) and high-level waste (HLW) fractions. A much larger amount of LAW is expected to result from retrieval, pretreatment, and immobilization processes. Per the Tri-Party Agreement (1994), both the LAW and HLW will be vitrified. It has been estimated that vitrification of the LAW waste will result in over 500000 metric tons or $200000 \mathrm{~m}^{3}$ of immobilized LAW (ILAW) glass. The DOE is proceeding with an approach to privatize the treatment and immobilization of Hanford's LAW and HLW. The DOE will provide these wastes to private contractors for treatment and immobilization and will receive the products (immobilized waste) for storage and ultimate disposal. The ILAW glass is to be disposed in an on-site near-surface burial facility.

It must be demonstrated that the disposal system will adequately retain the radionuclides and prevent contamination of the surrounding environment. Waste form performance is the first line of defense against releases of contaminants after disposal and an integral part of the multiple engineered barrier system (EBS). Mann et al. (1998) found that the release of radionuclides from the waste form via interaction/reaction with water is the prime threat to the environment surrounding the disposal site. The two major dose contributors in Hanford ILAW glass that must be retained are ${ }^{99} \mathrm{Tc}$ and ${ }^{79} \mathrm{Se}$.

McGrail et al. (1998) describe the strategy for testing and modeling to determine/assess the radionuclide release rates from ILAW glass. This strategy requires extensive testing and modeling for each glass considered. The resources required to perform such a thorough study on a large number of glasses are prohibitive. The Tanks Focus Area (TFA) Immobilization Program has outlined a task to reduce DOE's risk of accepting an ILAW glass that will not meet performance expectations. The TFA task is highly integrated with the Performance Assessment (PA) task described by McGrail et al. (1998). In the TFA task, the long-term performance of glasses is to be screened as a function of glass

\footnotetext{
${ }^{\text {a }}$ Operated by Battelle for the U.S. Department of Energy under Contract DE-AC06-76RLO 1830.
} 
composition. The first step in the TFA Immobilization Program was to document a literature survey of test methods and strategies that could be used to support the definition of an acceptable glass composition region (AGCR) (Vienna et al. 1999).

In this study, a team from Pacific Northwest National Laboratory (PNNL) and Westinghouse Savannah River Company (WSRC) propose to systematically vary the composition of a representative LAW glass and measure the impacts of this variation on responses from accelerated laboratory corrosion tests. This data set will be used to bound a glass composition region likely to have acceptable long-term behavior in the Hanford ILAW burial facility. However, the final determination of the acceptability of glasses identified under this effort rests with the ILAW PA Program. In the plan described here, we discuss the first stage of a two-stage study to develop the AGCR for Hanford ILAW glasses. The second stage will be planned with the knowledge gained from the first stage and concurrent work on the Hanford PA study (described in McGrail et al. 1998). In the second phase, a second tier of glass compositions designed to better define the AGCR will be tested.

\section{Expert Panel}

The TFA Immobilization Program convened a panel of experts to discuss and decide upon an approach to developing an AGCR for the Hanford ILAW product. Those present at the meeting are listed in Table I, along with their affiliation and area of expertise. A consensus approach was identified for developing a composition region with a low risk of not meeting the performance goals of the Hanford burial site.

Table I. List of attendees at approach meeting

\begin{tabular}{ll}
\hline Name & Affiliation \\
\hline Prof. David Clark & Univ. of Florida \\
Prof. Patricia Dove & Georgia Tech. \\
Dr. Bill Ebert & ANL \\
Mr. John Harbour & WSRC \\
Dr. Bill Holtzscheiter & WSRC \\
Dr. Pavel Hrma & PNNL \\
Dr. Carol Jantzen & WSRC \\
Dr. B. Pete McGrail & PNNL \\
Dr. David Peeler & WSRC \\
Prof. Ian Pegg & CUA \\
Prof. Joe Simmons & Univ. of Florida \\
Dr. Gary Smith & PNNL \\
Dr. Denis Strachan & PNNL \\
Mr. John Vienna & PNNL \\
Dr. Thomas Weber & Consultant \\
Dr. George Wicks & WSRC \\
Prof. Michael Weinberg & Univ. of Arizona \\
\hline
\end{tabular}


The panel concluded that the preferred set of tests could not be performed with the resources available. The panel settled on the following set of tests as the most scientifically defensible given the resource constraints:

- the vapor-phase hydration test (VHT) at $150^{\circ} \mathrm{C}$ for 14 days,

- the product consistency test (PCT-A) at $90^{\circ} \mathrm{C}$ with a glass surface area to solution volume $(\mathrm{S} / \mathrm{V})$ of $2000 \mathrm{~m}^{-1}$ for 7 days, and

- the PCT-B at $90^{\circ} \mathrm{C}$ with a $\mathrm{S} / \mathrm{V}$ of $20000 \mathrm{~m}^{-1}$ for multiple times up to roughly 1 year.

Results from the VHT will give information about the sccondary phases that are likely to form during the dissolution of glasses in very concentrated solutions at very high reaction extents. This test will also give a "quick screen" of glasses that are expected to perform very poorly in other, longer term, corrosion tests. The high S/V PCT (referred to as PCT-B) results will describe the static corrosion behavior of glasses as a function of time. The data from these tests can be used directly to rank glass compositions for durability or can serve as validation for modeling of performance of glass as a function of time and composition. The 7-day PCT (referred to as PCT-A) will serve as the first data point in the long-term PCT-B map of corrosion behavior and will help to determine the appropriate times for sampling. This test will also serve as a link between the measurements being performed in this study with the very large and growing database of glass testing with the PCT-A method.

\section{Test Matrix Design}

In order to identify the impacts of composition on the long-term corrosion behavior of glass and to develop an AGCR, glasses with systematic variation in composition must be tested. We discuss the development of a matrix of test glasses with systematically varied compositions. ${ }^{b}$ The basis of the experimental design is a single-component change for most compositional variables and a $4 \times 2$ factorial design for the major compositional variables. In both cases, the components that are not specifically varied in any particular glass are maintained in the same relative proportion as the centroid or baseline glass.

The test matrix was designed with the intent to be broad enough to include glasses with both acceptable and unacceptable long-term corrosion behavior. It encompasses those compositions that were developed by the Hanford Vitrification Vendor (HVV), including the expected variations in waste composition, glass additive composition, and waste loading. Resource constraints limited the number of glasses to approximately 50 , which could be fabricated and tested in the first phase of this study. The number of independent variables assessed with this number of glasses and type of design is

\footnotetext{
${ }^{b}$ The design of mixture experiments has been extensively studied (Cornell 1990, for example). Glass compositions are mixtures and are constrained by the fact that the fractions of glass components $\left(\mathrm{x}_{\mathrm{i}}\right)$ must sum to one: $\sum_{i} x_{i}=1$. Many types of designs are possible and have been used in mixture experiments. Examples of mixture designs include slack variable, simplex, and extreme vertices. To choose the proper design type and to implement the design, knowledge of the form of the experimental response in required. The long-term corrosion behavior of glass is expected to be discontinuous with glass composition. This expected discontinuity and not well understood balance between structural and geochemical aspects of long-term performance require the first-stage design to be one that will allow easy visualization and interpretation of results.
} 
nine. It was thus decided to choose a waste composition and vary its content in the glass as an independent variable rather than vary the individual components of waste as components in the glass. This reduces the ability to assess the impact of waste composition on glass behavior. However, the waste stream consists of between 84 and $96 \mathrm{wt} \% \mathrm{Na}_{2} \mathrm{O}$ and at this stage, the impact of other waste components is considered to be of secondary importance. The impacts of waste components on glass corrosion could be evaluated using a subsequent matrix.

Table II lists the compositions of expected Hanford LAW streams by tank. The waste composition chosen as a variable in this study is that in $\mathrm{AN}-105$. This is one of four tanks that contain over 1,000 $\mathrm{Mg}$ (metric tons) of soluble Na. This tank has a composition that appears to be near the center of waste compositions with high $\mathrm{Na}^{\mathrm{c}}$ Although $\mathrm{Tc}$ behavior is of interest to the PA, the current phase of this study will use Re as a stand-in for Tc. For this study, the concentration of Tc in AN-105 waste was increased by an order-of-magnitude and replaced on a molar basis by $\mathrm{Re}$, yielding $0.05 \mathrm{wt} \% \mathrm{ReO}_{2}$ in the waste simulant.

Table II. Composition and $\mathrm{Na}$ mass $\left(\mathrm{M}_{\mathrm{Na}}\right)$ estimates for Hanford LAW excluding radionuclides, minor components $(\leq .01 \mathrm{wt} \%)$ and major glass additive components $\left(\mathrm{SiO}_{2}, \mathrm{Al}_{2} \mathrm{O}_{3}\right.$, and $\left.\mathrm{Fe}_{2} \mathrm{O}_{3}\right)$

\begin{tabular}{lrllllllll}
\hline Tank & $\mathrm{M}_{\mathrm{Na}}(\mathrm{Mg})$ & $\mathrm{Na}_{2} \mathrm{O}$ & $\mathrm{Cl}^{-}$ & $\mathrm{SO}_{3}$ & $\mathrm{P}_{2} \mathrm{O}_{5}$ & $\mathrm{Cr}_{2} \mathrm{O}_{3}$ & $\mathrm{~F}^{-}$ & $\mathrm{K}_{2} \mathrm{O}$ & $\mathrm{CaO}$ \\
\hline $\mathrm{AN}-102$ & $\mathbf{1} 060$ & 94.88 & 0.52 & 1.64 & 0.99 & 0.29 & 0.26 & 1.29 & 0.13 \\
$\mathrm{AN}-103$ & 960 & 94.69 & 1.15 & 0.15 & 0.18 & 0.64 & 0.08 & 3.10 & 0.02 \\
$\mathrm{AN}-104$ & 1,100 & 95.50 & 1.08 & 0.43 & 0.59 & 0.59 & 0.00 & 1.79 & 0.03 \\
$\mathrm{AN}-105$ & $\mathbf{1 , 0 9 0}$ & $\mathbf{9 5 . 6 2}$ & $\mathbf{1 . 3 2}$ & $\mathbf{0 . 3 5}$ & $\mathbf{0 . 2 6}$ & $\mathbf{0 . 3 6}$ & $\mathbf{0 . 0 4}$ & $\mathbf{1 . 9 7}$ & $\mathbf{0 . 0 6}$ \\
$\mathrm{AN}-107$ & 803 & 96.18 & 0.51 & 1.98 & 0.14 & 0.28 & 0.00 & 0.76 & 0.15 \\
$\mathrm{AW}-101$ & 991 & 87.29 & 0.74 & 0.12 & 0.45 & 0.21 & 0.00 & 11.15 & 0.04 \\
$\mathrm{AZ}-101$ & 359 & 89.32 & 0.06 & 4.45 & 0.57 & 1.44 & 0.51 & 3.56 & 0.08 \\
$\mathrm{AZ}-102$ & 197 & 84.15 & 0.00 & 8.20 & 0.14 & 2.64 & 0.42 & 4.19 & 0.24 \\
$\mathrm{SY}-101$ & 1,330 & 93.13 & 1.44 & 0.16 & 1.32 & 2.51 & 0.00 & 1.36 & 0.08 \\
$\mathrm{SY}-103$ & 660 & 95.48 & 1.69 & 0.02 & 1.16 & 0.06 & 0.00 & 1.52 & 0.06 \\
\hline Min & & 84.15 & 0.00 & 0.02 & 0.14 & 0.06 & 0.00 & 0.76 & 0.02 \\
Mean & & 92.62 & 0.85 & 1.75 & 0.58 & 0.90 & 0.13 & 3.07 & 0.09 \\
Max & & 96.18 & 1.69 & 8.20 & 1.32 & 2.64 & 0.51 & 11.15 & 0.24 \\
\hline
\end{tabular}

With the modified AN-105 LAW composition, a baseline glass was formulated. The glass additive components considered by the $\mathrm{HVV}$ included $\mathrm{SiO}_{2}, \mathrm{Al}_{2} \mathrm{O}_{3}, \mathrm{~B}_{2} \mathrm{O}_{3}, \mathrm{Fe}_{2} \mathrm{O}_{3}, \mathrm{TiO}_{2}, \mathrm{ZnO}, \mathrm{ZrO}_{2}$, and $\mathrm{MgO}$. The concentrations of these components were varied until the calculated melting temperature was $1150^{\circ} \mathrm{C}^{\mathrm{d}}$ and the concentrations were somewhat close to the center of the desired range. Table III lists the LAW simulant, additive, and baseline glass compositions. The range of component concentrations (high, low, and intermediate levels) were selected to encompass possible variations in glass

\footnotetext{
'In other words, AN-105 doesn't appear to be near the extreme in any single waste component.

${ }^{\mathrm{d}}$ The melting temperature was determined by setting the viscosity to $10 \mathrm{~Pa} \cdot \mathrm{s}$, calculated according to Hrma et al. (1994).
} 
composition and to include glasses expected to have acceptable and unacceptable long-term corrosion behavior. ${ }^{e}$ These levels are also listed in Table III.

Table III. Base glass composition, component ranges, and composition of reference glasses in wt\% oxides

\begin{tabular}{lcccccc}
\hline Oxide & AN-105 Simulant & Additives & Base Glass & Low & High & Intermediate \\
\hline $\mathrm{SiO}_{2}{ }^{*}$ & & 62.06 & 49.07 & 36.0 & 52.0 & 40.0 \\
$\mathrm{Al}_{2} \mathrm{O}_{3}{ }^{*}$ & & 8.85 & 7.00 & 4.0 & 11.94 & 9.0 \\
$\mathrm{~B}_{2} \mathrm{O}_{3}$ & & 12.65 & 10.00 & 6.0 & 12.0 & 8.0 \\
$\mathrm{Fe}_{2} \mathrm{O}_{3}{ }^{*}$ & & 6.96 & 5.50 & 0.0 & 9.0 & 3.0 \\
$\mathrm{TiO}_{2}$ & & 3.79 & 3.00 & 0.0 & 6.0 & - \\
$\mathrm{ZnO}$ & & 1.90 & 1.50 & 0.0 & 4.0 & - \\
$\mathrm{ZrO}_{2}$ & & 1.90 & 1.50 & 0.0 & 6.0 & - \\
$\mathrm{MgO}$ & & 1.90 & 1.50 & 0.0 & 4.0 & - \\
$\mathrm{Na}_{2} \mathrm{O}$ & 95.58 & & 20.00 & 16.0 & 23.0 & 18.0 \\
$\mathrm{~K}_{2} \mathrm{O}$ & 1.97 & & 0.41 & 0.3 & 0.5 & 0.4 \\
$\mathrm{CaO}^{-}$ & 0.06 & & 0.01 & 0.0 & 0.0 & 0.0 \\
$\mathrm{Cl}^{-}$ & 1.32 & & 0.28 & 0.2 & 0.3 & 0.2 \\
$\mathrm{SO}_{3}$ & 0.35 & & 0.07 & 0.1 & 0.1 & 0.1 \\
$\mathrm{P}_{2} \mathrm{O}_{5}$ & 0.26 & & 0.06 & 0.0 & 0.1 & 0.0 \\
$\mathrm{Cr}_{2} \mathrm{O}_{3}$ & 0.36 & & 0.08 & 0.1 & 0.1 & 0.1 \\
$\mathrm{~F}^{-}$ & 0.04 & & 0.01 & 0.0 & 0.0 & 0.0 \\
$\mathrm{ReO}_{2}$ & 0.05 & & 0.01 & 0.0 & 0.0 & 0.0 \\
$\mathrm{Loading}$ & 20.93 & 79.07 & & 16.74 & 24.06 & 18.83 \\
\hline
\end{tabular}

* $\mathrm{Al}_{2} \mathrm{O}_{3}$ and $\mathrm{Fe}_{2} \mathrm{O}_{3}$ are in $\mathrm{AN}-105 \mathrm{LAW}$ in significant quantities, however they are varied separately in this study as glass additives.

With the component concentration levels listed in Table III, a test matrix was defined. Table IV lists the glass compositions in the test matrix. The base glass is listed four times (glass numbers 1,25 , 26, and 43) to give an assessment of errors in glass fabrication and testing.

\footnotetext{
${ }^{\mathrm{e}}$ At this point, expectations on long-term performance are based on conjecture and anecdotal evidence.
} 
Table IV. Test glass component levels and compositions

\begin{tabular}{|c|c|c|c|c|c|c|c|c|c|c|c|c|c|c|c|c|c|c|c|c|c|c|c|c|c|c|}
\hline ID & \multicolumn{9}{|c|}{ Level in glass ${ }^{*}$} & \multicolumn{17}{|c|}{ Concentration in glass (mass percent) } \\
\hline \# & $\mathrm{Si}$ & $\mathrm{Al}$ & & $\mathrm{Fe}$ & $\mathrm{Ti}$ & $\mathrm{Zn}$ & $\mathrm{Zr}$ & $\mathrm{Mg}$ & $\mathrm{Na}$ & & & & & & $\operatorname{Lin} 0$ & $\mathrm{ZrO}_{2}$ & 2 & & & & $\mathrm{Cl}^{*}$ & & $\mathrm{P}_{2} \mathrm{O}_{5}$ & $\mathrm{Cr}_{2} \mathrm{O}_{3}$ & & $\mathrm{ReO}_{2}$ \\
\hline 2 & & $\mathrm{~m}$ & I & $\mathrm{m}$ & $\mathrm{m}$ & m & M & & m & & & & & & & & & & & & & & & & & \\
\hline 4 & & $\mathrm{~m}$ & & & $\mathrm{~m}$ & $\mathrm{~m}$ & M & $\mathrm{m}$ & $\mathrm{m}$ & & & & & & & & & & & & & & & & & \\
\hline 5 & $n$ & 1 & $m$ & $m$ & $m$ & $m$ & M & $m$ & $\mathrm{~m}$ & & & & & & & & & & & & & & & & & \\
\hline 6 & & $\mathrm{~h}$ & $\mathrm{~m}$ & $\mathrm{~m}$ & $\mathrm{~m}$ & $\mathrm{~m}$ & $\mathrm{M}$ & $\mathrm{m}$ & $\mathrm{m}$ & & 11.94 & & & & & & & & & & & & & & & \\
\hline 9 & & $\mathrm{~m}$ & $\mathrm{~h}$ & $\mathrm{~m}$ & $\mathrm{~m}$ & $\mathrm{~m}$ & $\mathbf{M}$ & $\mathrm{m}$ & $\mathrm{m}$ & & 6.84 & & & 93 & & & & & & & & & & & & \\
\hline 10 & & $\mathrm{~m}$ & $\mathrm{i}$ & $\mathrm{m}$ & $\mathrm{m}$ & $\mathrm{m}$ & M & & $\mathrm{m}$ & & & & & 06 & & & & & & & & & & & & \\
\hline 11 & & $\mathrm{~m}$ & $\mathrm{~m}$ & 1 & $\mathrm{~m}$ & $\mathrm{~m}$ & M & & $\mathrm{m}$ & & & & & & & & & & & & & & & & & \\
\hline 12 & $\mathrm{~m}$ & $\mathrm{~m}$ & $\mathrm{~m}$ & $\mathrm{~h}$ & $\mathrm{~m}$ & $\mathrm{~m}$ & $\mathbf{M}$ & & $\mathrm{m}$ & & & & & & & & & & & & & & & & & \\
\hline 13 & & $\mathrm{~m}$ & $\mathrm{~m}$ & $\mathrm{i}$ & $\mathrm{m}$ & $\mathrm{m}$ & M & & $\mathrm{m}$ & & & & & & & & & & & & & & & & & \\
\hline 14 & & $\mathrm{~m}$ & $\mathrm{~m}$ & $\mathrm{~m}$ & 1 & $\mathrm{~m}$ & M & 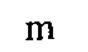 & $\mathrm{m}$ & & & & & & & & & & & & & & & & & 0 \\
\hline 15 & & $\mathrm{~m}$ & $\mathrm{~m}$ & $\mathrm{~m}$ & h & $\mathrm{m}$ & $\mathbf{M}$ & $\mathrm{m}$ & $\mathrm{m}$ & & & & & & & & & & & & & & & & & \\
\hline 2 & & $\mathrm{~m}$ & & min & & $\mathrm{m}$ & N & 1 & & & & & & & & & & & & & & & & & & \\
\hline 21 & & $\mathrm{~m}$ & $\mathrm{n}$ & $\mathrm{m}$ & & $\mathrm{m}$ & M & & $\mathrm{m}$ & & & & & & & & & & & & & & & & & \\
\hline 22 & & $\mathrm{~m}$ & $\mathrm{~m}$ & $\mathrm{~m}$ & $\mathrm{~m}$ & $\mathrm{~m}$ & M & $\mathrm{m}$ & 1 & & & & & & & & & & & & & & & & & \\
\hline 23 & & $\mathrm{~m}$ & $\mathrm{~m}$ & $\mathrm{~m}$ & $\mathrm{~m}$ & $\mathrm{~m}$ & $\mathbf{M}$ & $\mathrm{m}$ & $\mathrm{h}$ & & & & & & & & & & & & & & & & & .0 \\
\hline 24 & $m$ & $\mathrm{~m}$ & $\mathrm{~m}$ & $\mathrm{~m}$ & $\mathrm{~m}$ & $\mathrm{~m}$ & M & $\mathrm{m}$ & $\mathrm{i}$ & & & & & & & & & & & & & & & & & .0 \\
\hline 25 & $m$ & $m$ & $m$ & $m$ & $m$ & $\mathrm{~m}$ & $\mathbf{M}$ & $\mathrm{m}$ & $\mathrm{m}$ & & & & & & & & & & & & & & & & .01 & .0 \\
\hline 26 & in & $\mathrm{m}$ & $\mathrm{m}$ & $\mathrm{m}$ & $\mathrm{m}$ & $\mathrm{m}$ & M & & $\mathrm{m}$ & & & & & & & & & & & & & & & & .01 & .0 \\
\hline 27 & $n$ & $\mathrm{~h}$ & h & $\mathrm{m}$ & $\mathrm{m}$ & $\mathrm{m}$ & $\mathrm{M}$ & & h & & & & & .00 & & & & & & & & & & & & 1.0 \\
\hline 28 & 11 & $\mathrm{~h}$ & h & $\mathrm{m}$ & $\mathrm{m}$ & $\mathrm{m}$ & M & & 1 & & & & & 1.69 & & & & & & & & 06 & & & .01 & 0.0 \\
\hline 29 & in & $\mathrm{h}$ & l & $\mathrm{m}$ & $\mathrm{m}$ & $\mathrm{m}$ & M & & h & & & & & 1.38 & 0.69 & 0.69 & & & & & & 0.08 & 0.00 & U) & 0.01 & 0.0 \\
\hline 30 & 11 & $\mathrm{~h}$ & 1 & $\mathrm{~m}$ & $\mathrm{~m}$ & $\mathrm{~m}$ & M & & 1 & & & & & 3.07 & & & & & & & & 0.06 & 0.04 & .0 & 0.01 & 0.0 \\
\hline & $h$ & l & $\mathrm{h}$ & $\mathrm{m}$ & $\mathrm{m}$ & $\mathrm{m}$ & M & & h & 52.00 & 4.00 & 12.00 & 3.36 & 1.83 & 0.92 & 0.92 & 0.92 & 23.00 & & 70.01 & 0.32 & 0.08 & 0.06 & 0.09 & 0.01 & -0.0 \\
\hline
\end{tabular}




\begin{tabular}{|c|c|c|c|c|c|c|c|c|c|c|c|c|c|c|c|c|c|c|c|c|c|c|c|c|c|c|}
\hline ID & \multicolumn{9}{|c|}{ Level in glass ${ }^{*}$} & \multicolumn{17}{|c|}{ Concentration in glass (mass percent) } \\
\hline$\#$ & $\mathrm{Si}$ & $\mathrm{Al}$ & B & $\mathrm{Fe}$ & $\mathrm{Ti}$ & $\mathrm{Zn}$ & $\mathrm{Zr}$ & $\mathrm{Mg}$ & $\mathrm{Na}$ & $\mathrm{SiO}_{2}$ & $\mathrm{Al}_{2} \mathrm{O}_{3}$ & $\mathrm{~B}_{2} \mathrm{O}_{3}$ & $\mathrm{Fe}_{2} \mathrm{O}_{3}$ & $\mathrm{TiO}_{2}$ & $\mathrm{ZnO}$ & $\mathrm{ZrO}_{2}$ & $\mathrm{MgO}$ & $\mathrm{Na}_{2} \mathrm{O}$ & $\mathrm{K}_{2} \mathrm{O}$ & $\mathrm{CaO}$ & $\mathrm{Cl}^{-}$ & $\mathrm{SO}_{3}$ & $\mathrm{P}_{2} \mathrm{O}_{5}$ & $\mathrm{Cr}_{2} \mathrm{O}_{3}$ & $\mathbf{F}$ & $\mathrm{ReO}_{2}$ \\
\hline 32 & $\mathrm{~h}$ & l & $\mathrm{h}$ & $\mathrm{m}$ & $\mathrm{m}$ & $\mathrm{m}$ & $\mathrm{M}$ & $\mathrm{m}$ & 1 & 52.00 & 4.00 & 12.00 & 6.46 & 3.52 & 1.76 & 1.76 & 1.76 & 16.00 & 0.33 & 0.01 & 0.22 & 0.06 & 0.04 & 0.06 & 0.01 & 0.01 \\
\hline 33 & $\mathrm{~h}$ & 1 & 1 & $\mathrm{~m}$ & $\mathrm{~m}$ & $\mathrm{~m}$ & $\mathrm{M}$ & $\mathrm{m}$ & h & 52.00 & 4.00 & 6.00 & 5.90 & 3.21 & 1.61 & 1.61 & 1.61 & 23.00 & 0.47 & 0.01 & $\mathbf{0 . 3 2}$ & 0.08 & 0.06 & 0.09 & 0.01 & 0.01 \\
\hline 34 & $\mathrm{~h}$ & I & I & $\mathrm{m}$ & $\mathrm{m}$ & $\mathrm{m}$ & M & $\mathrm{m}$ & 1 & 52.00 & 4.00 & 6.00 & 9.00 & 4.90 & 2.45 & 2.45 & 2.45 & 16.00 & 0.33 & 0.01 & 0.22 & 0.06 & 0.04 & 0.06 & 0.01 & 0.01 \\
\hline 35 & 1 & h & h & $\mathrm{m}$ & $\mathrm{m}$ & $\mathrm{m}$ & $\mathbf{M}$ & $\mathrm{m}$ & h & 36.00 & 11.94 & 12.00 & 6.77 & 3.69 & 1.85 & 1.85 & 1.85 & 23.00 & 0.47 & 0.01 & 0.32 & 0.08 & 0.06 & 0.09 & 0.01 & 0.01 \\
\hline 36 & 1 & $h$ & h & $\mathrm{m}$ & $\mathrm{m}$ & $\mathrm{m}$ & $\mathrm{M}$ & $\mathrm{m}$ & 1 & 36.00 & 11.94 & 12.00 & 9.87 & 5.38 & 2.69 & 2.69 & 2.69 & 16.00 & 0.33 & 0.01 & 0.22 & 0.06 & 0.04 & 0.06 & 0.01 & 0.01 \\
\hline 37 & 1 & h & 1 & $\mathrm{~m}$ & $\mathrm{~m}$ & $\mathrm{~m}$ & $\mathbf{M}$ & $\mathrm{m}$ & h & 36.00 & 11.94 & 6.00 & 9.31 & 5.07 & 2.54 & 2.54 & 2.54 & 23.00 & 0.47 & 0.01 & 0.32 & 0.08 & 0.06 & 0.09 & 0.01 & 0.01 \\
\hline 38 & 1 & h & 1 & $\mathrm{~m}$ & $\mathrm{~m}$ & $\mathrm{~m}$ & $\mathrm{M}$ & $\mathrm{m}$ & 1 & 36.00 & 11.94 & 6.00 & 12.41 & 6.76 & 3.38 & 3.38 & 3.38 & 16.00 & 0.33 & 0.01 & 0.22 & 0.06 & 0.04 & 0.06 & 0.01 & 0.01 \\
\hline 39 & 1 & 1 & h & $\mathrm{m}$ & $\mathrm{m}$ & $\mathrm{m}$ & M & $\mathrm{m}$ & h & 36.00 & 4.00 & 12.00 & 10.13 & 5.52 & 2.76 & 2.76 & 2.76 & 23.00 & 0.47 & 0.01 & 0.32 & 0.08 & 0.06 & 0.09 & 0.01 & 0.01 \\
\hline 40 & 1 & 1 & h & $\mathrm{m}$ & $\mathrm{m}$ & $\mathrm{m}$ & $\mathbf{M}$ & $\mathrm{m}$ & 1 & 36.00 & 4.00 & 12.00 & 13.23 & 7.21 & 3.61 & 3.61 & 3.61 & 16.00 & 0.33 & 0.01 & 0.22 & 0.06 & 0.04 & 0.06 & 0.01 & 0.01 \\
\hline 41 & 1 & 1 & 1 & $m$ & $m$ & $\mathrm{~m}$ & $\mathbf{M}$ & $\mathrm{m}$ & h & 36.00 & 4.00 & 6.00 & 12.67 & 6.90 & 3.45 & 3.45 & 3.45 & 23.00 & 0.47 & 0.01 & 0.32 & 0.08 & 0.06 & 0.09 & 0.01 & 0.01 \\
\hline 42 & 1 & 1 & 1 & $\mathrm{~m}$ & $\mathrm{~m}$ & $\mathrm{~m}$ & M & $\mathrm{m}$ & l & 36.00 & 4.00 & 6.00 & 15.77 & 8.59 & 4.30 & 4.30 & 4.30 & 16.00 & 0.33 & 0.01 & 0.22 & 0.06 & 0.04 & 0.06 & 0.01 & 0.01 \\
\hline 43 & $\mathrm{~m}$ & $\mathrm{~m}$ & $\mathrm{~m}$ & $\mathrm{~m}$ & $\mathrm{~m}$ & $\mathrm{~m}$ & $\mathbf{M}$ & $\mathrm{m}$ & $\mathrm{m}$ & 49.07 & 7.00 & 10.00 & 5.50 & 3.00 & 1.50 & 1.50 & 1.50 & 20.00 & 0.41 & 0.01 & 0.28 & 0.07 & 0.06 & 0.08 & 0.01 & 0.01 \\
\hline
\end{tabular}

The symbols are: 1 - lower level in glass, $\mathrm{m}$ - medium level in glass (varies in proportion to all other " $\mathrm{m}$ " components to fix the sum of concentrations at 1 ), $\mathrm{h}$ - higher level in glass, and $\mathrm{i}$ - third "intermediate" level in glass. Levels are given in Table III. 
In addition to the 43 glasses listed in Table IV, seven additional glasses will be tested. These glasses are described below and three of the seven glasses are listed in Table V.

44) Glass number 44 is equivalent in composition to glass number 1 (base glass in Table V); however, it will be melted (and heat-treated) under a reducing atmosphere to produce a target $\mathrm{Fe}^{2+} / \mathrm{total}^{\mathrm{Fe}}$ ratio of roughly $10 \%$.

45) Glass number 45 is equivalent in composition to glass number 1; however, it will be melted (and heat-treated) under a reducing atmosphere to produce an $\mathrm{Fe}^{2+} /$ total $\mathrm{Fe}$ ratio of roughly $30 \%$.

Glasses 44 and 45 will be used to assess the impact of melt redox on glass corrosion characteristics. The HVV plans to process glass in a reducing environment.

46) The LD6-5412 glass is in the matrix since a very large and growing database on the corrosion characteristics of this glass has accumulated (Feng et al. 1996, Ebert et al. 1998, McGrail et al. $1997[\mathrm{a}, \mathrm{b}])$. This glass composition is outside of the ranges of test glasses in $\mathrm{SiO}_{2}, \mathrm{CaO}$, and $\mathrm{K}_{2} \mathrm{O}$ and slightly outside the range of $\mathrm{Al}_{2} \mathrm{O}_{3}$. However, because of the large database of corrosion measurements for this glass, it will make an ideal validation for this study.

47) LRM-1 glass is in the matrix since it is an analytical standard LAW glass. This glass composition is outside of the ranges of test glasses in $\mathrm{SiO}_{2}, \mathrm{~K}_{2} \mathrm{O}, \mathrm{Cl}^{-}$and $\mathrm{F}$. However, because it is a reference standard glass, corrosion data are being generated for this glass on this and other projects (Wolf et al. 1998).

Table V. Additional glasses compared to composition ranges (in wt $\%$ oxides)

\begin{tabular}{lccccccc}
\hline Oxide & Base Glass & Low & High & Intermediate & LD6-5412 & LRM-1 & LAW-B \\
\hline $\mathrm{SiO}_{2}$ & 49.07 & 36.0 & 52.0 & 40.0 & 55.44 & 53.50 & 43.93 \\
$\mathrm{Al}_{2} \mathrm{O}_{3}$ & 7.00 & 4.0 & 11.94 & 9.0 & 12.17 & 9.60 & 8.03 \\
$\mathrm{~B}_{2} \mathrm{O}_{3}$ & 10.00 & 6.0 & 12.0 & 8.0 & 5.05 & 8.10 & 8.07 \\
$\mathrm{Fe}_{2} \mathrm{O}_{3}$ & 5.50 & 0.0 & 9.0 & 3.0 & 0.11 & 1.00 & 8.03 \\
$\mathrm{TiO}_{2}$ & 3.00 & 0.0 & 6.0 & - & 0.02 & 0.10 & 0.00 \\
$\mathrm{ZnO}$ & 1.50 & 0.0 & 4.0 & - & 0.14 & 0.00 & 3.99 \\
$\mathrm{ZrO}_{2}$ & 1.50 & 0.0 & 6.0 & - & 0.08 & 0.91 & 3.04 \\
$\mathrm{MgO}$ & 1.50 & 0.0 & 4.0 & - & 0.00 & 0.09 & 3.00 \\
$\mathrm{Li}_{2} \mathrm{O}$ & - & - & - & - & 0.00 & 0.00 & 4.08 \\
$\mathrm{Na}_{2} \mathrm{O}$ & 20.00 & 16.0 & 23.0 & 18.0 & 20.41 & 17.20 & 10.00 \\
$\mathrm{~K}_{2} \mathrm{O}$ & 0.41 & 0.3 & 0.5 & 0.4 & 1.66 & 1.20 & 0.36 \\
$\mathrm{CaO}^{-}$ & 0.01 & 0.0 & 0.0 & 0.0 & 4.12 & 0.51 & 7.03 \\
$\mathrm{Cl}^{-}$ & 0.28 & 0.2 & 0.3 & 0.2 & 0.00 & 1.10 & 0.29 \\
$\mathrm{SO}_{3}$ & 0.07 & 0.1 & 0.1 & 0.1 & 0.18 & 0.20 & 0.02 \\
$\mathrm{P}_{2} \mathrm{O}_{5}$ & 0.06 & 0.0 & 0.1 & 0.0 & 0.22 & 0.47 & 0.01 \\
$\mathrm{Cr}_{2} \mathrm{O}_{3}$ & 0.08 & 0.1 & 0.1 & 0.1 & 0.05 & 0.18 & 0.10 \\
$\mathrm{~F}^{-}$ & 0.01 & 0.0 & 0.0 & 0.0 & 0.00 & 0.85 & 0.00 \\
$\mathrm{ReO}_{2}$ & 0.01 & 0.0 & 0.0 & 0.0 & 0.00 & 0.00 & 0.00 \\
\hline $\mathrm{Total}$ & 100.00 & & & & 99.65 & 95.01 & 99.98 \\
\hline
\end{tabular}

\footnotetext{
${ }^{\mathrm{f}}$ The composition of LAW-A33 was omitted from Table V because it is proprietary to the HVV.
} 
48) The LAWA33 glass is in the matrix as this glass is representative of current HVV glass formulations. It is within the composition region and will be used for validation.

49) The HVV LAW-B (Ferrara et al. 1998) glass is in the matrix, as this glass is representative of recent $\mathrm{HVV}$ glass formulations. It is outside the component ranges for $\mathrm{Na}_{2} \mathrm{O}, \mathrm{CaO}$, and $\mathrm{Li}_{2} \mathrm{O}$ and will be used for validation.

50) If a suitable natural analog glass with well-characterized corrosion is found, it will be added as glass number 50 . This glass will help to show a correlation between the accelerated tests and corrosion in nature.

\section{Glass Fabrication and Testing}

The task of fabricating these 50 glasses will be divided between PNNL and WSRC. Glasses 1 through 25 will be fabricated at WSRC and glasses 26 through 49 will be fabricated at PNNL. The procedures used to fabricate glasses will be consistent at the two sites. The procedure includes the use of single metal oxide and carbonate precursors for all components accept $\mathrm{SO}_{3}, \mathrm{P}_{2} \mathrm{O}_{5}, \mathrm{~F}^{-}$, and $\mathrm{Cl}^{-}$, which will be added as sodium salts, and $\mathrm{B}_{2} \mathrm{O}_{3}$, which will be added as $\mathrm{H}_{3} \mathrm{BO}_{3}$. Batches sufficient to produce $500 \mathrm{~g}$ of glass will be melted in a covered $\mathrm{Pt} / \mathrm{Rh}$ crucible for $1 \mathrm{~h}$, quenched on a steel plate, ground in a tungsten carbide mill, and remelted in a covered $\mathrm{Pt} / \mathrm{Rh}$ crucible for $1 \mathrm{~h}$. After the second melt, a small portion of the melt will be quenched on a steel plate $(\sim 100 \mathrm{~g})$ the remainder of the melt will be heat treated according to the HVV box interior cooling schedule shown in Figure $1 . \mathrm{g}$

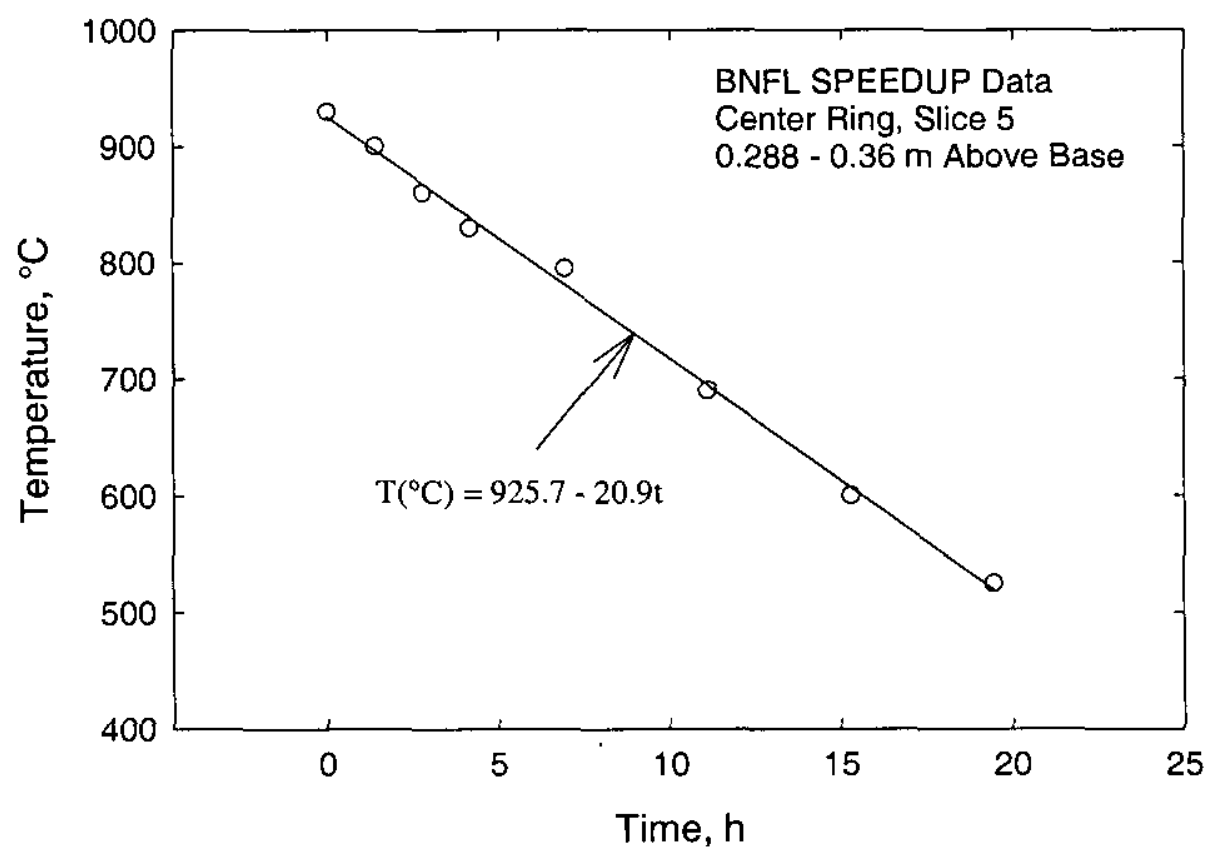

Figure 1. Computed thermal cooling curve for $1.2 \times 1.2 \times 1.8 \mathrm{~m}$ waste package

\footnotetext{
${ }^{\mathrm{g}}$ Glasses 46 and 47 will not be heat-treated, but bars will be cast and annealed for $2 \mathrm{~h}$ at $10^{\circ} \mathrm{C}$ above the glass transition temperature and slow cooled to room temperature. Glasses 44 and 45 will be melted and heat-treated in a controled atmosphere furnace with a fixed ratio of $\mathrm{CO} / \mathrm{CO}_{2}$ as cover gas to effect the proper iron redox condition. Glass 50 will not be melted.
} 
The heat-treated glass will be used in the PCT-A, PCT-B, and VHT. The PCT's will be performed on all glasses at the WSRC according to ASTM C-1285. The conditions for PCT-B measurements will be a S/V of $20000 \mathrm{~m}^{-1}$, a temperature of $90^{\circ} \mathrm{C}$, Teflon vessels, ${ }^{\text {h }}$ and will be performed in duplicate. The durations for PCT-B's will be evenly spaced in logarithmic time such as: $10 \mathrm{~h}, 100 \mathrm{~h}, 1000 \mathrm{~h}$, and 10000 h.' The PCT-A will follow the PCT-A procedure in ASTM C-1285 for all conditions and will be measured in triplicate. For verification purposes, the PCT-B's will be repeated at PNNL on selected glasses.

The VHT will be performed on all test glasses at PNNL according to internal technical procedures. ${ }^{j}$ The conditions for this test will be a temperature of $150^{\circ} \mathrm{C}$, a surface finish of 600 grit, and an amount of water equal to that required for saturation in the vessel plus $0.05 \mathrm{ml}$ per sample. Test durations will be evenly spaced in logarithmic time such as: $14 \mathrm{~d}, 23 \mathrm{~d}$, and $38 \mathrm{~d} .^{\mathrm{k}}$ The reaction layer thickness of test samples will be determined with optical microscopy (OM) and scanning electron microscopy (SEM). An attempt will be made to identify the secondary reaction phases on test glasses with OM, SEM with energy dispersive spectroscopy, and x-ray diffraction. VHT's will be performed in duplicate. Additional laboratory(s) (WSRC and/or Argonne National Laboratory) will perform VHT's on selected glasses according to the PNNL procedure for verification.

The composition of selected glasses will be measured using multiple fusions and inductively coupled plasma atomic emission spectroscopy and/or inductively coupled plasma mass spectroscopy. These determined compositions will be compared to target compositions for verification.

\section{Data Evaluation}

Data from PCT and VHT will be compiled and evaluated to define a preliminary AGCR and to plan the second phase of this study. The VHT data will first be used as a "quick" screen for glasses that demonstrate poor long-term corrosion behavior. The PCT data will follow and allow, when combined with VHT data, the rough calculation of a release rate from glass under burial conditions. The test results can be used to estimate the impact on meeting dose criteria for the ILAW PA with the following assumptions:

1. Glass surface area is approximately $10 \times$ the geometric area from thermal stress fracturing and this entire area is wetted in the disposal system(Perez and Westsik 1981 and Faletti and Ethridge 1986).

2. Radionuclide release rate from each waste package is identical and invariant in time and space.

\footnotetext{
${ }^{\mathrm{h}}$ When using Teflon vessels, $\mathrm{CO}_{2}$ is able to diffuse to the sample so that secondary reactions are not limited by $\mathrm{CO}_{2}$ concentration. However, for these long test durations, the vessel mass must be tracked and water added when the weight loss exceeds $10 \%$.

${ }^{i}$ A fifth sample may be initiated at the discretion of the tester with unknown test duration. This sample will then be terminated at a time determined upon review of initial data.

j The PNNL procedure for VHT is, "Vapor-phase Hydration Test Procedure," GDL-VHT, Rev. 1, PNNL, Richland, WA (1999).

${ }^{\mathrm{k}}$ Additional times were added to allow the determination of a corrosion rate.

${ }^{1}$ B. P. McGrail, Path Forward - Identifying ILAW Glass Formulations with Acceptable Processing and Long-Term Performance Characteristics, Internal Letter Report (1999)
} 
3. Tc is released congruently with dissolution of the glass matrix, i.e. Tc is not selectively leached nor is it sequestered into secondary phases.

Of these, the first assumption is the most uncertain. Although the geometric area of the glass blocks is reasonably well known, the effective surface area in the disposal system environment is not. It is not clear what fraction of the geometric surface area will be contacted by water or how waste aging may affect the effective surface area. Given these uncertainties, we conservatively use the geometric surface area. Calculations performed in the ILAW PA show that release of Tc from the disposal system must be on the order of $7.4 \mathrm{ppm} / \mathrm{yr}$ or less if the drinking water dose limit of 4 $\mathrm{mrem} / \mathrm{yr}$ to the maximum affected individual at $1 \mathrm{~km}$ from the site is to be achieved and no Tc is removed in processing of the waste before it is made into glass (Mann et al. 1998). The limiting glass corrosion rate is then given by:

$$
r_{d}^{\prime}=\frac{f_{r}^{\prime} \rho V}{A_{w}} \approx \frac{\left(7.4 \times 10^{-6}\right)\left(2.6 \times 10^{6}\right)\left(1.2^{3}\right)}{(6)\left(1.2^{2}\right)(10)(365)} \approx 1.0 \times 10^{-3} \mathrm{~g} /\left(\mathrm{m}^{2} \cdot d\right)
$$

where $r_{d}^{\prime}=$ limiting glass corrosion rate, $\mathrm{g} /\left(\mathrm{m}^{2} \cdot \mathrm{d}\right)$,

$f_{r}^{\prime}=$ required fractional release rate from disposal system, $\mathrm{ppm} / \mathrm{yr}$,

$\rho=$ glass density, $\mathrm{g} / \mathrm{m}^{3}$,

$V=$ volume of waste package, $\mathrm{m}^{3}$, and

$A_{w}=$ water contact area, $\mathrm{m}^{2}$.

In this calculation, the waste package was assumed to be a cube, $1.2 \mathrm{~m}$ on edge, and the glass density is assumed to be $2600 \mathrm{~kg} / \mathrm{m}^{3}$.

Having determined the limiting glass corrosion rate at burial site conditions, an extrapolation method is required to determine the equivalent limiting corrosion rate at the elevated temperature of the laboratory experiments. A ratio of corrosion rate at elevated temperature $\left(T_{E}\right)$ versus the burial temperature $\left(T_{B}\right)$ can be computed with an Arrhenius expression given by:

$$
\frac{r_{T_{E}}}{r_{T_{b}}}=\operatorname{Exp}\left[\frac{-E_{a}}{R}\left(\frac{1}{T_{E}}-\frac{1}{T_{B}}\right)\right]
$$

where $E_{a}$ is the apparent activation energy for corrosion. However, it is not clear what activation energy is appropriate. For glasses that undergo a sustained acceleration in corrosion rate, the activation energy measured under dilute solution conditions (forward reaction rate) may be appropriate. For stable glasses, secondary reaction processes (such as ion exchange) that have lower activation energy may dominate. For our purposes, we will use an activation energy of $78 \mathrm{~kJ} / \mathrm{mol}$, which is typical of the values measured for borosilicate glasses under dilute solution conditions. This will give a maximum value for $r_{T_{E}}$ and so expand the envelope of potentially acceptable glass compositions.

Using the acceptable rate at temperature generated from these calculations, the Tc concentration in glass, and the listed assumptions, glasses can be sorted into two categories: 1) those that pass the 
criteria (fall inside an AGCR), and 2) those that fail (fall outside the initial AGCR). With these assignments, a preliminary AGCR can be defined and the next phase of the study may then be planned. However, the initial definition of a preliminary AGCR will be only a tool to guide the next phase of study. It will not be sufficient to significantly lower the risk to DOE or be used in contract negotiations with the HVV. The final AGCR for ILAW, and hence the risk reduction, is planned to be completed after phase 2 of this study.

\section{References}

J. A. Cornell, Experiments with Mixtures: Design, Models, and the Analysis of Mixture Data, $2^{\text {nd }}$ ed. John Wiley and Sons, New York, NY (1990)

W. L. Ebert, A. J. Bakel, D. M. Strachan, and S. F. Wolf, Laboratory Testing of LD6-5412 Glass, DRAFT, Argonne National Laboratory, Argonne, IL (1998)

D. W. Faletti and L. J, Ethridge, Method for Predicting Cracking in Waste Glass Canisters, PNL5947, Pacific Northwest Laboratory, Richland, WA (1986)

X. Feng, P.R. Hrma, J.H. Westsik, M.J. Schweiger, H. Li, J.D. Vienna, G. Chen, G.F. Piepel, D.K. Peeler, D.E. Smith, B.P. McGrail, S.E. Palmer, D. Kim, Y. Peng, W.K. Hahn, A.J. Bakel, and W.L. Ebert, Glass Optimization for Vitrification of Hanford Site Low-Level Tank Waste. PNNL-10918, Pacific Northwest National Laboratory, Richland, WA (1996)

D. M. Ferrara, C. L. Crawford, B. C. Ha, and N. E. Bibler, "Vitrification of Three Low-Activity Radioactive Waste Streams From Hanford," Proceedings of the International Conference on Decommissioning and Decontamination and on Nuclear and Hazardous Waste Management, p. $706-$ 713, ANS, La Grange IL (1998)

P. R. Hrma, G. F. Piepel, M. J. Schweiger, D. E. Smith, D. S. Kim, P. E. Redgate, J. D. Vienna, C. A. LoPresti, D. B. Simpson, D. K. Peeler, and M. H. Langowski, Property/Composition Relationships for Hanford High-Level Waste Glasses Melting at $1150^{\circ} \mathrm{C}$, Volumes 1 and 2. PNL-1035, Pacific Northwest Laboratory, Richland, WA (1994)

F. M. Mann, R. J. Puish, P. D. Rittman, A. H. Lu, G. F. Williamson, N. R. Brown, P. E. LaMont, N. W. Kline, J. A. Voogd, Y. Chen, C. R. Eiholzer, C. T. Kincaid, and B. P. McGrail, Hanford Immobilized Low-Activity Tank Waste Performance Assessment, DOE/RL-97-69, U.S. Department of Energy, Richland, WA (1998)

B. P. McGrail, W. L. Ebert, A. J. Bakel, and D. K. Peeler, "Measurement of Kinetic Rate Law Parameters on a Na-Ca-Al Borosilicate Glass for Low-Activity Waste," Journal of Nuclear Materials vol. 249 , p. $175-189$ (1997a)

B. P. McGrail, C. W. Lindenmeier, P. F. Martin, and G. W. Gee, "The Pressurized Unsaturated Flow (PUF) Test: A New Method for Engineered-Barrier Materials Evaluation," Ceramic Transactions vol. 72 , p. 317-329 (1997b) 
B. P. McGrail, W. L. Ebert, D. H. Bacon, and D. M. Strachan, A Strategy to Conduct an Analysis of the Long-Term Performance of Low-Activity Waste Glass in a Shallow Subsurface Disposal System at Hanford, PNNL-11834, Pacific Northwest National Laboratory, Richland, WA (1998)

J. M. Perez and J. H. Westsik, Jr, "Effects of Cracks on Glass Leaching," Nuclear and Chemical Waste Management vol. 2, p. 165-168 (1981)

Tri-Party Agreement, Washington State Department of Ecology, U.S. Environmental Protection Agency, and U.S. Department of Energy, Hanford Federal Facility Agreement and Consent Order, 89-10, Rev. 3, Fourth Amendment, Olympia, WA (1994)

J. D. Vienna, P. Hrma, and D. K. Peeler, Product Acceptance for Hanford ILAW, PNNL-12117, Pacific Northwest National Laboratory, Richland, WA (1999)

S. F. Wolf, W. L. Ebert, J. S. Luo, and D. M. Strachan, A Data Base and Standard Material for Use in Acceptance Testing of Low-Activity Waste Products, ANL-98/9, Argonne National Laboratory, Argonne, IL (1998) 


\section{Westinghouse Savannah River Company Document Approval Sheet}

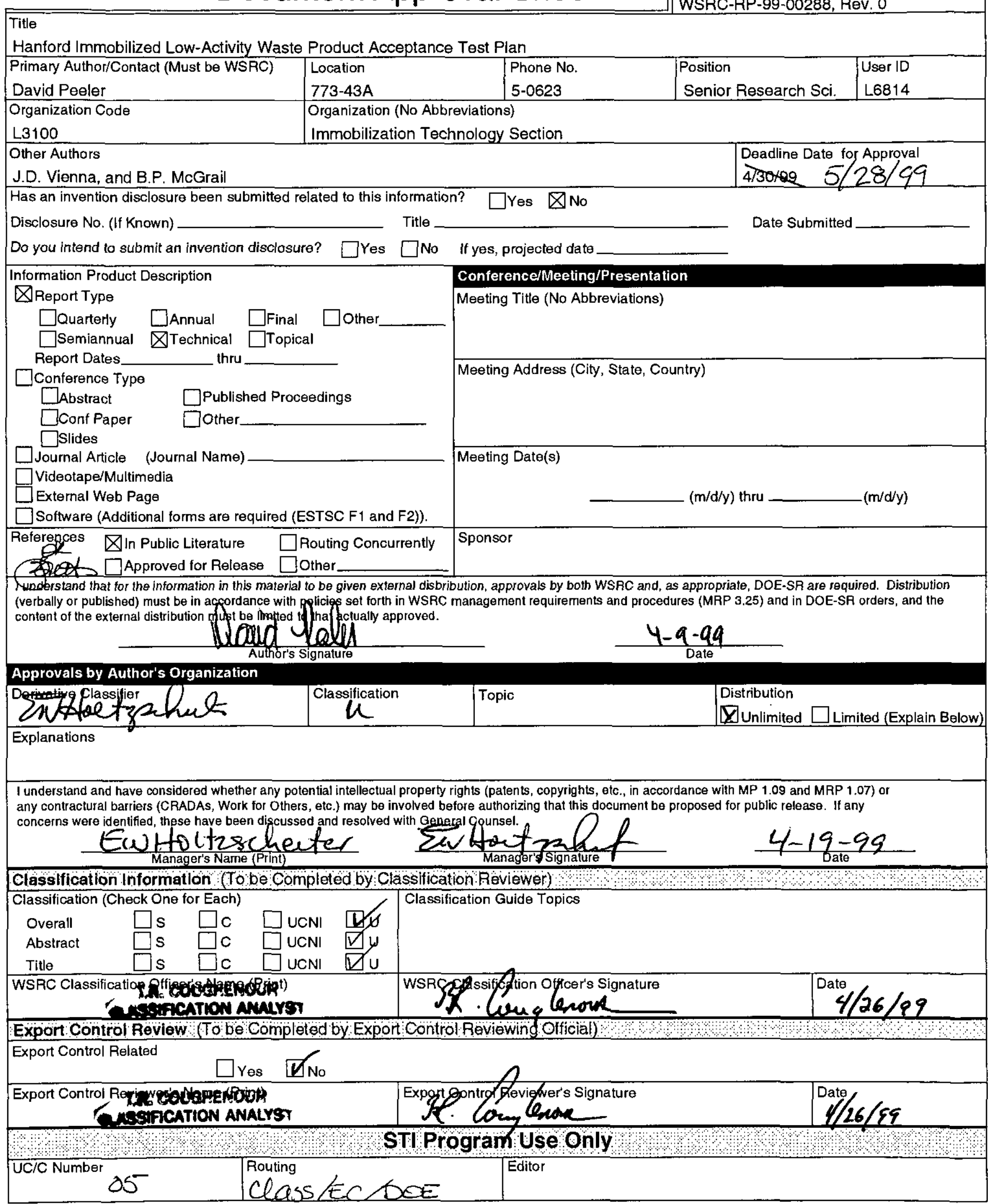

NOTE OSR 17-8 must be completed in addition to this form when submitting information for review and approval.

$$
\text { Keyporods: ser Records foum }
$$


Westinghouse

Savannah River Company
P.O. Box 616

Aiken, SC 29802

WSRC-RP-99-00288, Rev. 0

MSD-STI-97-4219

Ms. W. F. Perrin, Technical Information Officer

U.S. Department of Energy - Savannah River Operations Office

Dear Ms. Perrin:

REQUEST FOR APPROVAL TO RELEASE SCIENTIFIC/TECHNICAL INFORMATION

The attached document is submitted for classification and technical approvals for the purpose of external release. Please complete Part II of this letter and return the letter to the undersigned by 5/28/99. The document has been reviewed for classification and export control by a WSRC Classification staff member and has been determined to be Unclassified.

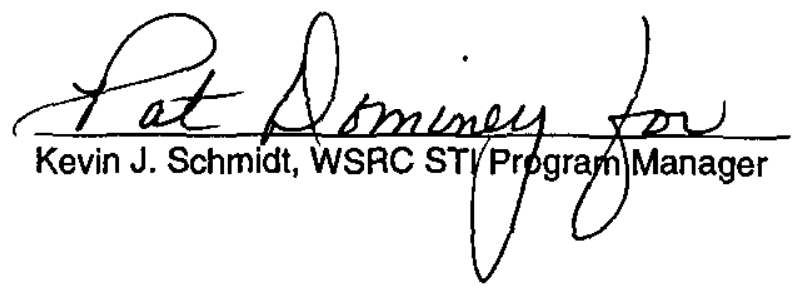

I. DETAILS OF REQUEST FOR RELEASE

Document Number: WSRC-RP-99-00288, Rev. 0

Author's Name: D. Peeler

Location: $773-43 \mathrm{~A}$

Phone 5-0623

Department: Immobilization Technology Section

Document Title: Hanford Immobilized Low-Activity Waste Product Acceptance Test Plan

Presentation/Publication:

Meeting/Journal:

Location:

$$
\text { DSTI Reportable }
$$

Meeting Date:

II. DOE-SR ACTION

Date Received by TIO $\quad 4 / 27 / 99$

Approved for Release

Approved Upon Completion of Changes $\triangle$ Approved with Remarks
Not Approved

Revise and Resubmit to DOE-SR

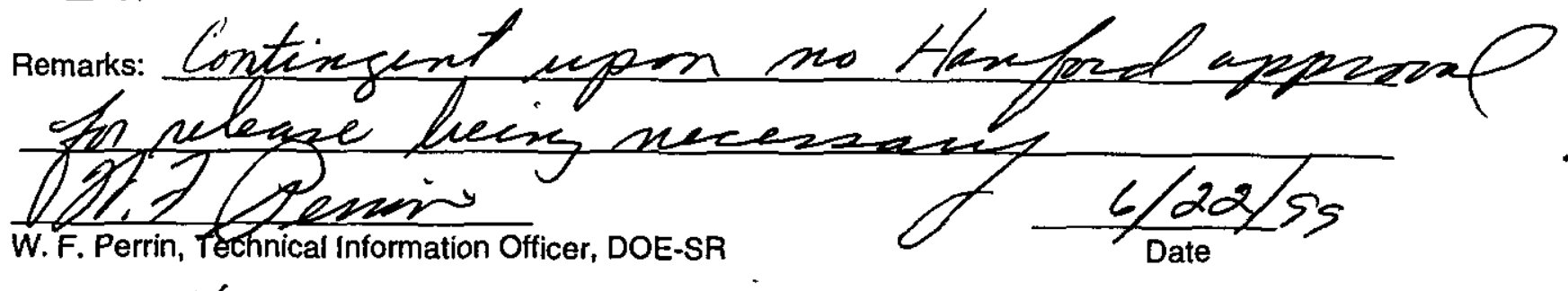

OSR 25-B2-W\# (4-89) Stores: 26-15460.00

Hanford personnel involved in divehepnent

tram ed by WSeC (work for others). No 


\section{ANNOUNCEMENT OF U. S. DEPARTMENT OF ENERGY (DOE) SCIENTIFIC AND TECHNICAL INFORMATION (STI)}

RECORD STATUS (select one):

X...New ......Revised Data ..... Zevised STI Product

Part I: STI PRODUCT DESCRIPTION

A. STI PRODUCT TYPE (select one)

X.. 1. Technical Report
a. Type: $\square$ Topical $\square$ Semiannual
b. Reporting Period ( $\mathrm{mm} / \mathrm{dd} / \mathrm{y} y \mathrm{y}$,

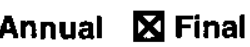
Other (specify)

2... 2. Conference
a. Product Type: ....... Conference Proceedings .....
Conference Paper or Other (abstracts, excerpts, etc.)
b. Conference Information (title, location, dates)

3. Software Manual ( The actual software package should be made available simultaneously. Follow instructions provided with ESTSC F 1 and ESTSCF2.)

..... 4. Journal Article
a. Type: $\quad \underline{X}$ Announcement citation onlv
Preprint
Postprint
b. Journal Name
c. Volume
d. Issue
e. Serial identifier (e.g., ISSN or CODEN)

..... 5. S\&T Accomplishment Report

..... 6. Book

..... 7. Patent Application
a. Date Filed $(\mathrm{mm} / \mathrm{dd} / \mathrm{y} y \mathrm{y})$
b. Date Priority $(\mathrm{mm} / \mathrm{dd} / \mathrm{yyy} y \mathrm{y})$
c. Patent Assignee

.... 8. Thesis/Dissertation

B. STI PRODUCT TITLE .Hanford.Ummakilized.Low-Activity..Waste.P.roduct.Ac.cegtance.Test.Plan

C. AUTHOR(s) $\quad$ D....... - Peepeler.

E-mail Address(es):

\section{STI PRODUCT IDENTIFIER}
1. Report Number(s) WSRG-RP.99-0.0288.ReX..Q
2. DOE Contract Number(s) _.RE-AC.09-96SR1.8500.
3. R\&D Project ID(s)
4. Other Identifying Number(s)

E. ORIGINATING RESEARCH ORGANIZATION Savannah River Site

F. DATE OF PUBLICATION ( $\mathrm{mm} / d d / y y y)$

G. LANGUAGE (if non-English) English

(Grantees and Awardees: Skip to Description/Abstract section at the end of Part I)

H. SPONSORING ORGANIZATION

I. PUBLISHER NAME AND LOCATION (if other than research organization)

Availability (refer requests to [if applicable])

J. SUBJECT CATEGORIES (list primary one first) $\quad 05$

Keywords _R.C.T.Chemical Compossition..TFA.

K. DESCRIPTION/ABSTRACT

The Hanford Site has been used to produce nuclear materials for the U.S. Department of Energy (DOE) and its predecessors. A large inventory of radioactive and mixed waste, largely generated during Pu production, exists in 177 underground single- and double-shell tanks. These wastes are to be retrieved and separated into low-activity waste (LAW) and high-level waste (HLW) fractions. The DOE is proceeding with an approach to privatize the treatment and immobilization of Handord's LAW and HLW. 


\section{ANNOUNCEMENT OF U. S. DEPARTMENT OF ENERGY (DOE) SCIENTIFIC AND TECHNICAL INFORMATION (STI)}

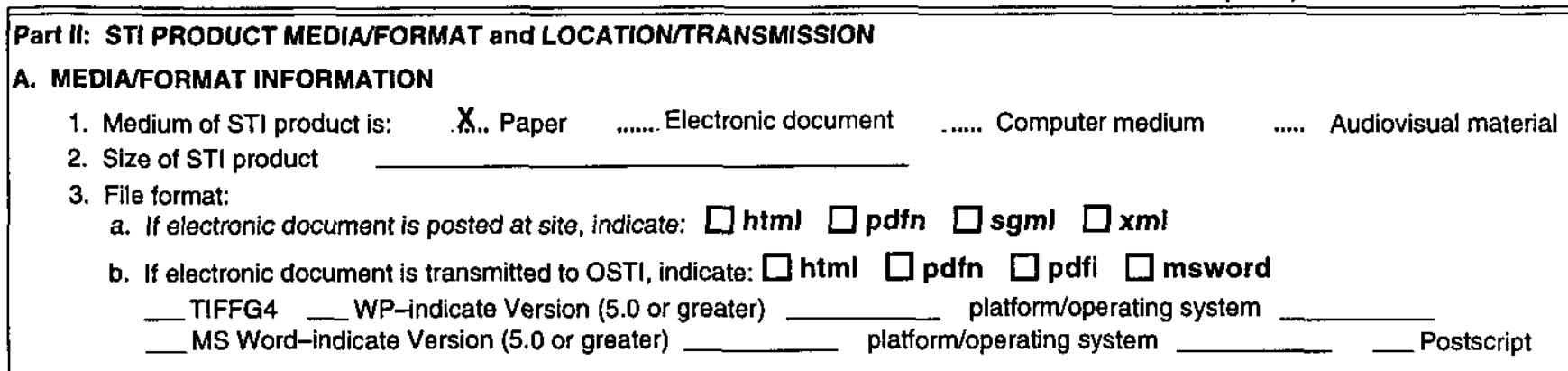

4. If computer medium or audiovisual material:
a. Quantity/type (specity)
b. Machine compatibility (specify)
c. Sound:
_yes)
d. Color (yes) ө. Tables/Graphics (yes)
f. Other information about product format a user needs to know:

\section{B. LOCATIONTRANSMISSION INFORMATION}

1. STI Product is available at site: Unique URL (of specific STI Product)

2. STI Product is being transmitted to OSTI:

a._Electronically via FTP

b. _ Via Mail or shipment (e.g., Federal Express) (Paper products, electronic documents on CD-ROM, diskettes, videocassettes, etc.)

3. Information Product Filename (of transmitted electronic format)

C. ADDITIONAL INFORMATION (concerning media/format or location/transmission; for OSTI internal use only):

(Grantees and Awardees: Skip to Contact section at the end of Part III)

Part III: STI PRODUCT REVIEW? RELEASE INFORMATION

A. ACCESS LIMITATION

X..... 1. Unlimited Announcement (available to U.S. and non-U.S. public)

........ 2. OpenNet (use OpenNet guidance for below):

a. If additional source other than making it available through NTIS:

e. OpenNet Document Type

(1) Accession Number

(2) Document Location

b. Field Office Acronym

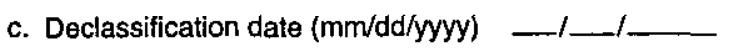

d. Declassification Status:

Declassified Sanitized __ Never classified

3. U.S. Dissemination Only

........... 4. Copyrighted material; Are there any restrictions based on copyright?

f. OpenNet Document Keywords

g. OpenNet Addressee yes no. If yes, list the restrictions

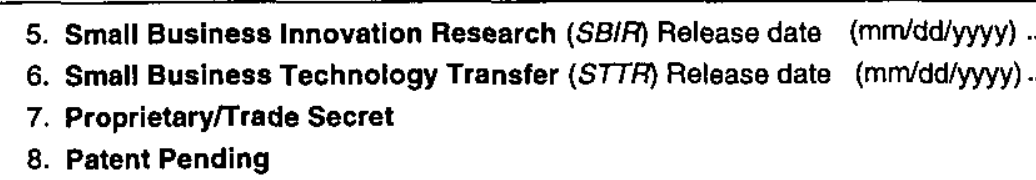
a. This form $U$.
b. The STI Product Uncelassified.

15. Other information relevant to access (specify; for OSTI intemal use only))

B. OTHER (information useful to include in published announcement record which is not suited for any other field on this form)

\section{CONTACT AND RELEASING OFFICIAL}

1.Contact (if appropriate, the organization or site contact to include in published citations who would receive any extemal questions about the content of the STI Product or the research information contained therein)

Name and/or Position K.J. Schmidt, Manager STI Program \& Site Support

E-mail Phone _(803) 725-2321

2. Releasing Official $\mathbf{X}$ I verify that all necessary reviews have been completed (e.g. Patent, Copyright, ECl, UCNI, etc.) Released by (name) K.J. Schmidt Date ( $\mathrm{mm} / \mathrm{dd} / \mathrm{y} / \mathrm{y} / \mathrm{y})$ E-Mall Phone 